Int. J. Electrochem. Sci., 11 (2016) 3467 - 3491

International Journal of

ELECTROCHEMICAL

SCIENCE

www.electrochemsci.org

\title{
Development of Novel Phosphorylated Cellulose Acetate Polyelectrolyte Membranes for Direct Methanol Fuel Cell Application
}

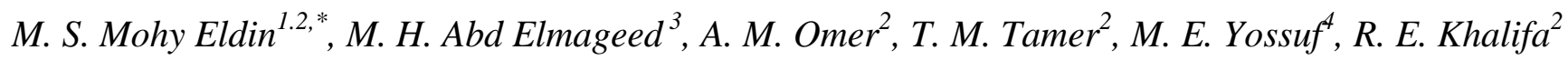 \\ ${ }^{1}$ Chemistry Department, Faculty of Science, University of Jeddah, Asfan, P. O. Box: 80203, Jeddah \\ 21589, Saudi Arabia \\ ${ }^{2}$ Polymer Materials Research Department, Advanced Technology and New Materials Research \\ Institute, MuCSAT, New Borg El-Arab City 21934, Alexandria, Egypt \\ ${ }^{3}$ Chemical Engineering Department, Faculty of Engineering, Alexandria University, Alexandria, \\ Egypt. \\ ${ }^{4}$ Computer-Based Engineering Applications Department, Informatics Research Institute, MuCSAT, \\ New Borg El-Arab City 21934, Alexandria, Egypt \\ *E-mail: m.mohyeldin@mucsat.sci.eg
}

doi: $10.20964 / 110318$

Received: 25 December 2015 / Accepted: 9 March 2016 / Published: 1 April 2016

A novel phosphorylated cellulose acetate membranes (PCA) was prepared using epichlorohydrin as an activating agent and evaluated as a potential polyelectrolyte membrane for DMFC applications. The PCA membranes exhibit higher water uptake, low methanol uptake. Thermal oxidation stability, TGA, and tensile characterization impelled good thermomechanical stability than the native CA membranes. Furthermore, the PCA membranes are found to have a low methanol permeability $\left(2.4 * 10^{-15} \mathrm{Cm}^{2} / \mathrm{S}\right)$ which much smaller than that of Nafion membranes $\left(1.14 * 10^{-9} \mathrm{Cm}^{2} / \mathrm{S}\right)$. The basic manufacture technology and cheapness of CA polymer recommend this candidate for fuel cells application. In conclusion, the formulated PCA membranes can be applied as new polyelectrolyte membranes for the DMFCs application.

Keywords: Activation; Phosphorization; Cellulose acetate membrane; Fuel cell; Ions exchange capacity, polyelectrolyte membranes.

\section{FULL TEXT}

(C) 2016 The Authors. Published by ESG (www.electrochemsci.org). This article is an open-access article distributed under the terms and conditions of the Creative Commons Attribution License (http://creativecommons.org/licenses/by/4.0/). 